\title{
ГЕОФІЗИКА
}

T. Pastushenko, PhD, Associate Professor Taras Shevchenko National University of Kyiv, Institute of Geology, 90 Vasylkivska Str., Kyiv

\section{ELECTRICAL PROPERTIES OF CAMBRIAN ROCKS IN VOLYNO-PODILLIA}

\section{(Рекомендовано членом редакційної колегії канд. геол. наук, старш. наук. співроб. І. М. Безродною)}

In this article, we present the results of applying a petroelectrical research technique to complex terrigenous and carbonate reservoirs. There have been determined the petroelectrical properties and their relation to porosity and permeability of sandstones, dolomites and limestones (Cambrian deposits) from the Volodymyrska area, Volyno-Podillia. The aim of the research was to build petroelectrical models of reservoir rocks to ensure a comprehensive analysis of electrical parameters of rocks and their correlation with porosity and permeability. Determining effective resistivity of reservoir rocks can provide data on: changes in different types and groups of rocks, stratigraphic horizons, facies and geological sections; correlations between effective resistivity and mineral composition, pore structure, substance phase ratio, electric field intensity and frequency; resistance variations due to epigenetic transformation and metamorphic changes in rocks.

Petrophysical laboratory studies included determining: bulk density of rocks (both dry and saturated with synthetic brine); effective porosity (obtained by nitration and synthetic brine saturation); residual water saturation factor (by centrifugation); permeability (by stationary nitrogen filtration method); interval time (P-wave velocity) and electrical resistivity. Laboratory research yielded data on the petroelectrical parameters of Cambrian sandstones, dolomites and limestones from the hydrocarbon prospective Volodymyrska area, as well as empirical correlations between petroelectrical parameters, porosity and permeability of the studied rocks.

It has been found that the electrical resistivity of the dry extracted samples (mainly determined by electrical resistance of the rock matrix) ranges from 5,2.104 Ohms $m$ (sandstones) to 2,4.107 (dolomites), with an average value of 3,8.106. The electrical resistivity of synthetic brine saturated rock samples ( $\mathrm{NaCl}$ solution) ranges from 7,2 Ohms $m$ (sandstones) to 73 (limestones), with an average value of 45. The formation resistivity factor ranges from 20,4 to 85,5, with an average value of 44,1 (sandstones); from 143,9 to 207,6, with an average value of 188,6 (limestones); from 81,7 to 198,7, with an average value of 155.6 (dolomites). The variation range of the resistance increase is: from 1 to 3,24, with an average value of 1,24 (sandstones); from 1 to 7,19, with an average value of 2,24 (limestones); from 1 to 2,76 , with an average value of 1,44 (dolomites). Sandstones are characterized by changes in resistance from 1 to 2,12 , with an increase in pressure from atmospheric to hydrostatic (to $59 \mathrm{MPa}$ ), while for limestones the resistivity index ranges from 1 to 7,7 , with pressure ranging between 0-49 $\mathrm{MPa}$.

There have been found correlations between electrical resistivity and porosity ratio, as well as resistance increase and the water saturation ratio in the laboratory and reservoir conditions, which may be used as a framework for geological interpretation of geophysical data. These correlation dependences are generally approximated by the power function. Data analysis shows that petroelectrometric studies are a powerful tool in laboratory and field research, being efficient enough to give extensive and useful information about rock properties. Laboratory data on electrical resistance of rocks may be employed to further reinforce the interpretation of the results of electrometric well logging and electric exploration.

Key words: core, water saturation, fluid, borehole, Cambrian, sandstone, limestone, dolomite, centrifuge, porosity, electrical resistivity, pressure, permeability, petroelectrical parameters, correlation dependence.

Introduction. The intricate correlation between porosity, permeability and logging and field geophysical data requires a thorough analysis based on petrophysical laboratory studies. A crucial factor in determining the geoelectrical properties of rocks is electrical resistivity $(\rho)$, which is determined by rock composition and texture, capacity space structure, oil- gasand water saturation of rocks, porosity factor, reservoir water salinity, temperature and pressure [1-8].

Our main purpose was to develop a petroelectrical model of reservoir rocks so as to provide the basis for a comprehensive analysis of their electrical parameters and their relation to porosity and permeability. Determining reservoir rock resistivity is essential to clarifying its variation range for certain types and groups of rocks, determining individual stratigraphic horizons, sections and facies; revealing the correlation between resistivity and a number of attributes, such as mineral composition, pore space structure, the phase relation of matter, frequency and tension of the electric field, as well as identifying the nature of changes in electrical resistivity under epigenetic transformations and metamorphic changes in rocks.

Laboratory data on resistivity variation in rocks are used in electrical logging interpretation and electrical exploration.

This paper presents the results of petroelectrical laboratory analysis of Cambrian sandstones, limestones and dolomites from the hydrocarbon prospective Volodymyrska area
(Volodymyrska-1 and Volodymyrska-2 wells, the interval $1,190-2,520 \mathrm{~m})$. The area is located in the northern part of the eastern side of the Lviv Paleozoic rock bend in Volyno-Podillia edge of the East-European platform.

Experiment. A series of laboratory experiments involved identifying the density of the rocks under study (dry and saturated with synthetic brine), open porosity (method of nitrogen saturation and method of synthetic brine saturation), residual water saturation factor (by centrifugation), permeability (nitrogen filtration method), interval time (velocity of P-waves) and resistivity. In the laboratory experiments, we determined electrical resistivity of rock samples under various conditions (dry, partially and completely saturated with reservoir synthetic brine) under atmospheric conditions and under those similar to in-situ conditions.

Laboratory electrometric measurements of dry core samples were performed at a temperature of $20^{\circ} \mathrm{C}$ with a digital teraohmmeter C.A. 6547, which ensures highprecision measurement of electrical resistivity in the range of $10 \mathrm{kOhms}$ to 10 TOhms, using a DC twoelectrode scheme, with computerized digital recording [37]. For $\mathrm{NaCl}(\mathrm{M}=30 \mathrm{~g} / \mathrm{l})$ saturated samples, $\mathrm{RCL}$-meter MHC-1100 was used. Cylindrical samples to be tested were placed in a special core holder with nonpolarized electrodes, which are specially made from graphitized rubber. In order to determine the correlation between the petrophysical parameters and the water saturation levels

(C) Vyzhva S., Onyshchuk D., Onyshchuk V., Pastushenko T., 2014 
(and hence oil and gas saturation) of rocks, we studied the changes in resistivity while stripping water on centrifuge OC-6M.

Petroelectrical analysis involved repeated measuring of electrical resistivity in core samples saturated with synthetic brine. Measurements were performed before and after centrifugation in stripping modes from 1,000 to 6,000 $\mathrm{rev} / \mathrm{min}$ with a measurement interval of $1,000 \mathrm{rev} / \mathrm{min}$, water displacement pressure ranging from 0,2 to $1,0 \mathrm{MPa}$ (7 measurement cycles). Simultaneously, water saturation factor and velocity of elastic waves were being determined. The mean relative error of electrical resistance was estimated to be $2,4 \%$.
Data analysis. Petrophysical laboratory research yielded data on porosity, permeability and electric properties of the major types of rocks, as shown in Table 1.

The laboratory measurements have shown that resistivity values measured on dry extracted samples (electrical resistivity of the rock matrix) range from 51,610 (sandstone) to $24,441,890 \mathrm{Ohms} \cdot \mathrm{m}$ (dolomites), with an average of $3,827,440 \mathrm{Ohms} \cdot \mathrm{m}$. Major variations in the resistivity values of the samples are due to inhomogeneities in the texture of rocks (the presence of clay and sandy layers) and their disarray. Specific electrical resistivity of rock samples saturated with synthetic brine $(\mathrm{NaCl}$ solution) ranges from 7,2 (sandstones) to $73 \mathrm{Ohms} \cdot \mathrm{m}$ (limestones) with an average value of $45 \mathrm{ohms} \cdot \mathrm{m}$.

Table 1

Results of measuring petrophysical properties of limestones, dolomites and sandstones

\begin{tabular}{|c|c|c|c|c|c|c|c|c|c|c|c|c|}
\hline \multirow[b]{2}{*}{ Index } & \multirow[b]{2}{*}{ Rock } & \multirow[b]{2}{*}{ Age } & \multirow[b]{2}{*}{$\begin{array}{c}\text { Parameter } \\
\text { Value }\end{array}$} & \multicolumn{2}{|c|}{ Density, $\mathrm{kg} / \mathrm{m}^{3}$} & \multicolumn{2}{|c|}{ Open porosity, \% } & \multirow[b]{2}{*}{$\begin{array}{l}\text { Perme- } \\
\text { ability, } \\
\text { femtom2 }\end{array}$} & \multirow{2}{*}{$\begin{array}{c}\text { Residual } \\
\text { Water } \\
\text { Saturation } \\
\text { Factor }\end{array}$} & \multicolumn{2}{|c|}{ Resistivity, Ohms·m } & \multirow[b]{2}{*}{$\begin{array}{c}\text { Resistivity } \\
\text { factor }\end{array}$} \\
\hline & & & & dry & $\begin{array}{c}\mathrm{NaCl} \\
\text { saturated }\end{array}$ & $\begin{array}{c}\text { with } \\
\text { nitrogen }\end{array}$ & $\begin{array}{c}\mathrm{NaCl} \\
\text { saturated }\end{array}$ & & & dry & $\begin{array}{c}\mathrm{NaCl} \\
\text { saturated }\end{array}$ & \\
\hline 1 & 2 & 3 & 4 & 5 & 6 & 7 & 8 & 9 & 10 & 11 & 12 & 13 \\
\hline 1 & limestones & $\epsilon$ & $\min$ & 2,661 & 2,673 & 0,01 & 0,002 & 0,001 & 0,03 & 131,110 & 50,5 & 143,9 \\
\hline 2 & limestones & $\epsilon$ & $\max$ & 2,699 & 2,704 & 0,025 & 0,013 & 3,479 & 0,67 & $6,588,358$ & 72,9 & 207,6 \\
\hline 3 & limestones & $\epsilon$ & avg & 2,690 & 2,695 & 0,016 & 0,006 & 0,442 & 0,269 & $1,423,156$ & 66,2 & 188,6 \\
\hline 4 & dolomites & $\epsilon$ & $\min$ & 2,690 & 2,694 & 0,017 & 0,005 & 0,001 & 0,3 & 146,508 & 28,7 & 81,7 \\
\hline 5 & dolomites & $\epsilon$ & $\max$ & 2,845 & 2,854 & 0,046 & 0,038 & 0,002 & 0,65 & $24,441,890$ & 69,8 & 198,7 \\
\hline 6 & dolomites & $\epsilon$ & avg & 2,753 & 2,766 & 0,026 & 0,017 & 0,001 & 0,41 & $6,411,826$ & 54,6 & 155,6 \\
\hline 7 & sandstones & $\epsilon$ & $\min$ & 2,116 & 2,222 & 0,054 & 0,044 & 0,005 & 0,27 & 51,610 & 7,2 & 20,4 \\
\hline 8 & sandstones & $\epsilon$ & $\max$ & 2,486 & 2,526 & 0,13 & 0,116 & 1,067 & 0,86 & $11,127,988$ & 30 & 85,5 \\
\hline 9 & sandstones & $\epsilon$ & avg & 2,290 & 2,361 & 0,089 & 0,077 & 0,139 & 0,71 & $3,647,329$ & 15,5 & 44,1 \\
\hline
\end{tabular}

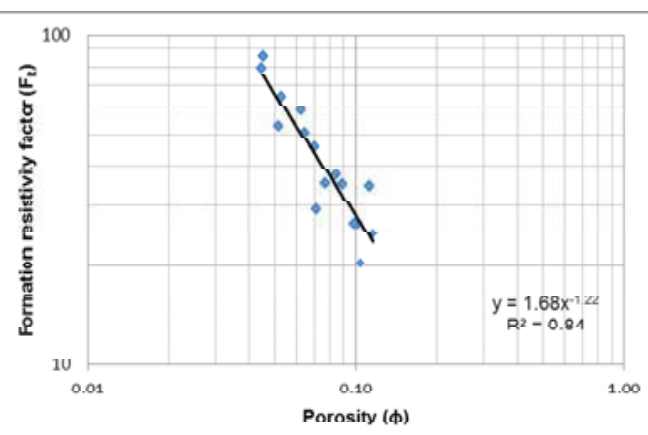

a

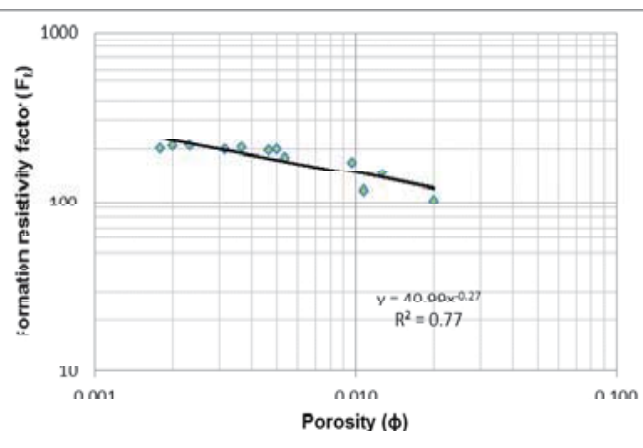

b

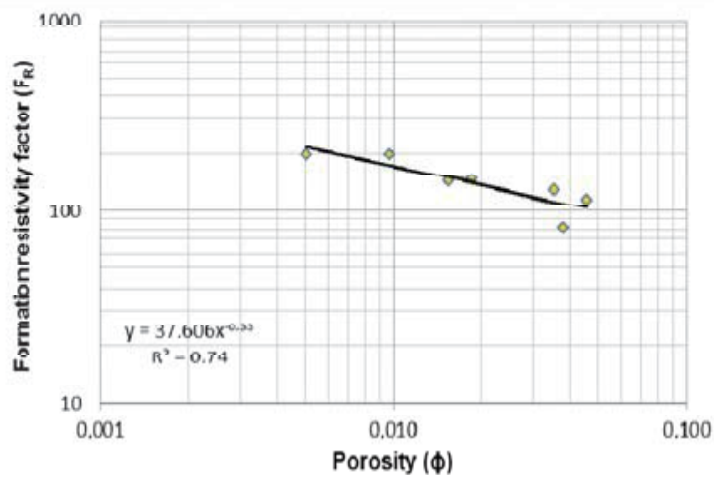

C

Fig. 1. Correlation between porosity $(\phi)$ and the formation resistivity factor (FR) Archie-Dahnov Equation (laboratory conditions):

$\mathrm{a}$ - sandstone, $\mathrm{b}$ - limestone, $\mathrm{c}$ - dolomite

Our laboratory studies showed the following correlation (Fig. 1a, 1b, 1c) between porosity $(\phi)$ and the formation resistivity factor $\left(F_{R}\right): F=a \cdot \phi^{-m}-$ Archie-Dahnov Equation for sandstone, limestone and dolomite, respectively, where $a$ is constant coefficient, and $m-$ structural indicator [7].
Electrical resistivity can be quantified using ArchieDahnov Equation: $F_{R}=1.675 \cdot \phi^{-1.22}$ where $R^{2}=0.835$ (sandstones), $F_{R}=40.99 \cdot \phi^{-0.27}$, where $R^{2}=0.77$ (lime- 
stones), $F_{R}=37.60 \cdot \phi^{-0.33}, R^{2}=0.74$ (dolomites), where $F_{R}=\mathrm{R}^{0} / \mathrm{R}_{\mathrm{W}}, \mathrm{R}^{0}$ - the resistivity of a $100 \%$ water saturated rock, $R_{W}$ - electrical resistivity of reservoir water.

Data analysis showed that in sandstones, relative changes in formation resistivity factor range from 20.4 to 85.5 , with an average value of 50 . Accordingly, porosity variation is within the range of 0.089 to 0.116 , with an average value of 0.077 . For limestone, variation in formation resistivity ranges from 143.9 to 207.6 , with an average value of 180 , whereas porosity varies from 0.002 to 0.015 , with an average value of 0.008 . Dolomites show variation in formation resistivity factor ranging from 81.7 to 198.7 , with an average value of 145 , and porosity variation of 0.005 to 0.038 , with an average value of 0.017 .

Limestone and dolomite from Volodymyrska area show little difference in the values: coefficient $a$ is 41 and 36.6 respectively, and the structural index $m-0.273$ and 0.33 .
On the other hand, for sandstones from the Volodymyrska area, coefficient $a$ is 1.675 , and structural index $m-1.124$, these values being markedly different from those above.

We used the centrifuge OC-6M in our laboratory experiment and carried out statistical analysis of petroelectrical measurements to determine the correlation between resistivity index $\left(I_{R}\right)$ and water saturation factor $\left(S_{w}\right)$ for the rocks under study. Correlation dependences are as follows: for sandstones $-I_{R}=1.069 \cdot S_{w}^{-0.92}$, with $R^{2}=0.82$, for the limestones the relationship is: $I_{R}=1.169 \cdot S_{w}^{-0.79}$, with $\mathrm{R}^{2}=0.86$; dolomites dependence can be expressed by the following formula: $I_{R}=0.997 \cdot S_{w}^{-0.87}$, with $R^{2}=0.79$, where $I_{R}=R_{t} / R_{o}, R_{o}$ - partially water-saturated rock resistivity and $R_{t}$ is water-saturated rock resistivity. Fig. $2 a, 2 b$ and $3 c$ show the correlations:

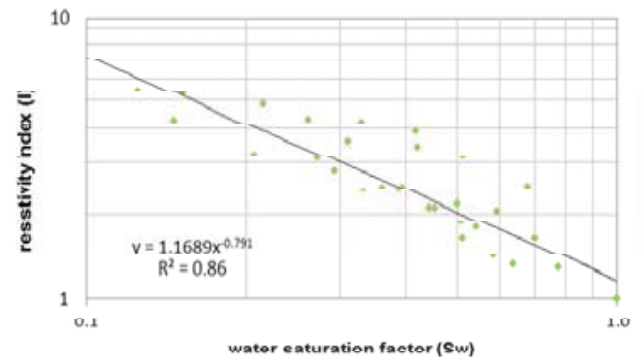

b

a

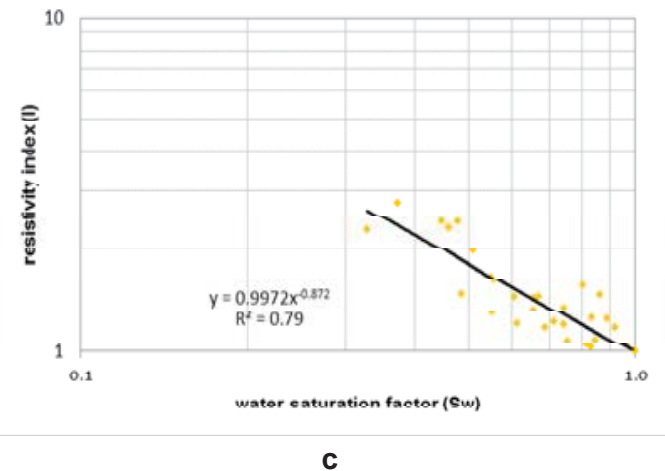

Fig. 2. Correlation between water saturation factor (Sw) and resistivity index (IR):

a - sandstones, $\mathrm{b}$ - limestones, $\mathrm{c}$ - dolomites

Data analysis shows that the sandstones have a resistivity index ranging from 1 to 3.23 , with an average value of 1.24. Accordingly, water saturation factor ranges from 1 to 0.29 , with an average value of 0.88 . For limestones, resistivity index variation is from 1 to 7.19 , with an average value of 2.24 and water saturation factor ranging from 1 to 0.08 , with an average value of 0.48 . For dolomites, resistivity index ranges from 1 to 2.76 , with an average value of 1.44 and the corresponding water saturation factor varying from 1 to 0.33 , with an average value of 0.71 .

It should be noted, that in the correlation equation $\mathrm{I}_{\mathrm{R}}=\mathrm{b} \cdot \mathrm{S}_{\mathrm{w}}^{-\mathrm{n}}$ which expresses the relationship between water saturation factor and resistivity index, coefficient $b$ varies from 0.997 (dolomites) to 1.17 (limestones), and wet-

$$
\mathrm{Q}=1 \times 10^{-5} \mathrm{p}^{3}-13 \times 10^{-4} \times \mathrm{p}^{2}+5.9 \times 10^{-2} \times \mathrm{p}+0.9993 \text {, with } \mathrm{R}^{2}=0.99 \text { (sandstones), }
$$$$
\mathrm{Q}=-8 \cdot 10^{-6} \cdot \mathrm{p}^{4}+9 \cdot 10^{-4} \cdot \mathrm{p}^{3}-2.98 \cdot 10^{-2} \cdot \mathrm{p}^{2}+4.022 \cdot p+0.4302 \text {, with } \mathrm{R}^{2}=0.99 \text { (limestones). }
$$

Figures $3 \mathrm{a}$ and $3 \mathrm{~b}$ show this relationship.

Sandstones show a variation of resistivity increasing coefficient ranging from 1 to 2.12 , with an increase in the hydrostatic pressure from the atmospheric pressure up to tability index $n$ ranges from 0.79 (limestones) to 0.92 (sandstones). The rocks under study show little difference in these attributes.

To evaluate specific resistivity of rocks in situ, we carried out a comprehensive study using a special high pressure installation - VSC-1000, with pressure ranging from the atmospheric pressure to $59 \mathrm{MPa}$. The results clearly show that under increasing pressure, closing of microcracks and deformation of the pore space result in an increase in the electrical resistivity of rocks. We have been able to define the correlation between the mean value of the resistivity increase coefficient $(Q)$ and pressure $(p)$ for sandstones and limestones. This relationship can be expressed by polynomials of order 3 and 4 :

$59 \mathrm{MPa}$. For the limestones, the variation range of resistivity increasing coefficient is from 1 to 7.7 , with an increase in the hydrostatic pressure from the atmospheric pressure up to $59 \mathrm{MPa}$. 


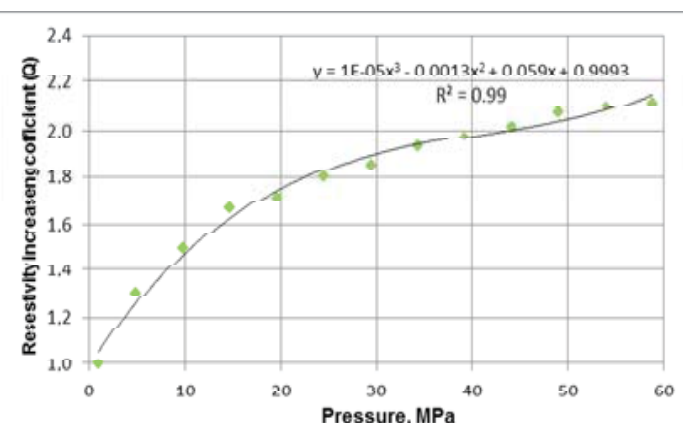

a

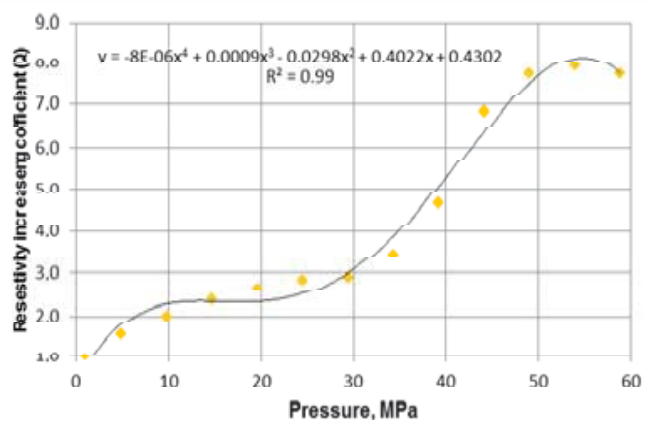

b

Fig. 3. Correlation between the resistivity increasing coefficient $(Q)$ and pressure $(p)$ for: sandstones (a) and limestones (b)

Graphs in Fig. 3 suggest that there are three areas showing marked differences in the nature of electric resistivity variation. In the first area, where pressure ranges from the atmospheric pressure to $24.5 \mathrm{MPa}$, resistivity increasing coefficient is very high - up to 1.8 for sandstones. This may be caused by intense closing of microcracks, which reduces channels conductivity. The following range of pressure variation - from 24.5 to $44 \mathrm{MPa}$ - is associated with a certain stabilization of electrical resistivity variation. In this case the coefficient of resistivity increasing ranges from 1.8 to 2 for sandstones. In the range of pressures from 44 to $59 \mathrm{MPa}$ resistivity increasing coefficient is lower than in the first range, but higher than in the second one. The slow growth rate of the resistivity increasing coefficient in the ranges (plots) 2 and 3 may be accounted for by relatively smaller (than in the first range) deformations of the pore space, which constricts or breaks the conduction channels. For limestones, in the first section (pressure increases from atmospheric to $9.8 \mathrm{MPa}$ ) the resistivity increasing coefficient varies from 1 to 2 . In the range of pressures from 9.8 to $29 \mathrm{MPa}$, there is some stabilization in electrical resistivity variation to be observed. With pressure increasing above $30 \mathrm{MPa}$, the resistivity increasing coefficient rises sharply (up to 7.7 at a pressure of $59 \mathrm{MPa}$ ). This is probably due to abrupt closing of major cracks responsible for electrical conductivity.

Using the data on measuring resistivity under pressure, we calculated its values for the rocks in situ. A petroelectrical study with high pressures applied enabled us to define the relationship between porosity $(\boldsymbol{\phi})$ and formation resistivity factor $\left(F_{R}\right)$ in situ. The Archie-Dahnov Equation for the Cambrian sandstones (in situ) is as follows (Fig. 4): $\mathrm{F}_{\mathrm{R}}=1.365 \cdot \varphi^{-1.52}$, with $\mathrm{R}^{2}=0.92$.

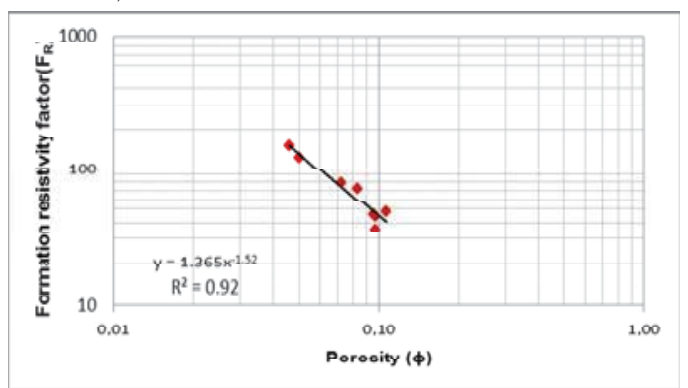

Fig. 4. Correlation between porosity $(\phi)$ and formation resistivity factor (FR) under in situ conditions for the Cambrian sandstones

To evaluate electrical anisotropy, we took measurements of electrical resistivity along and across the stratification. Resistivity anisotropy coefficient $\lambda$ was determined using the formula:

$$
\lambda=\sqrt{\frac{R_{v}}{R_{h}}}
$$

where $R_{h}$ and $R_{v}=$ electrical resistivity along and across stratification respectively.

The results show that the resistivity anisotropy coefficient of dry extracted sandstones varies from 1.01 to 1.09 , with an average value of 1.05. Anisotropy factor of saturated ( $\mathrm{NaCl}$ solution) sandstones ranges from 1.05 to 1.18 , with an average value of 1.12 .

A comprehensive analysis of the petrophysical data set was the basis for determining petroelectrical models of consertal sandstones, limestones and dolomites. In this paper, the petroelectrical model is presented in the form of geoelectrical data and relationships between petroelectrical parameters and physical properties of the Volodymyrska area rocks. These data are summarized in Table 2.

Conclusions. We have shown that, being a powerful tool for both laboratory and field studies, electrometric methods prove to be effective and provide extensive and accurate data on the properties of rocks. Petroelectrical study plays an important role in petrophysics and is widely used in determining the physical properties of rocks and ores. Determining their composition, structure and condition is essential for solving various tasks in mineral exploration, particularly in petroleum geology.

Laboratory experiment has been conducted in order to determine the petroelectrical attributes of Cambrian sandstones, limestones and dolomites from the hydrocarbon prospective Volodymyrska area. It was found that the electrical resistivity of the dry extracted samples (determined mainly by electrical resistance of the rock matrix) ranges from $5.2 \cdot 10^{4}$ Ohms $\cdot \mathrm{m}$ (sandstones) to $2.4 \cdot 10^{7}$ (dolomites), with an average value of $3.8 \cdot 10^{6}$. The electrical resistivity of rock samples saturated with synthetic brine ( $\mathrm{NaCl}$ solution) ranges from $7.2 \mathrm{Ohms} \cdot \mathrm{m}$ (sandstones) to 73 (limestones), with an average value of 45 . The formation resistivity factor ranges from 20.4 to 85.5 with an average value of 44.1 (sandstones); from 143.9 to 207.6 , with an average value of 188.6 (limestones); from 81.7 to 198.7 , with an average value of 155.6 (dolomites). The variation range of the resistance increase is: from 1 to 3.24 , with an average value of 1.24 (sandstones); from 1 to 7.19 , with an average value of 2.24 (limestones); from 1 to 2.76 , with an average value of 1.44 (dolomites). Sandstones are characterized by changes in resistance from 1 to 2.12 with an increase in pressure from atmospheric to hydrostatic (to $59 \mathrm{MPa}$ ), while for limestones the resistivity index ranges from 1 to 7.7, with pressure ranging between 0-49 MPa. Our study has revealed empirical relationships between petroelectrical parameters and filtration-capacity properties of sandstones, limestones and dolomites, which are essential to the geological interpretation of geophysical data. These 
relationships are approximated by a power function.

Extensive petroelectrical research into the properties of sandstones, limestones and dolomites has ensured accurate petroelectrical models of these rocks based on geological and geophysical data. The models show significant differences in the electrical parameters of sandstones, limestones and dolomites. These models can become a powerful tool in studying the petrophysical properties of different rock types. Further research into petroelectrical properties of rocks will require data on dielectric permeability, dielectric loss tangent, as well as evaluating the relevance of geoelectric parameters which account for variation in electrical resistivity of dry extracted samples exposed to direct current over longer periods of time and establishing their correlations with logging data.

Petroelectrical models of rocks (wells Volodymyrska-1 and Volodymyrska-2,

Table 2 the interval 1,190-2,520 m) from Volodymyrska area

\begin{tabular}{|c|c|c|c|c|}
\hline \multirow[t]{2}{*}{ Index } & \multirow{2}{*}{$\begin{array}{l}\text { Petroelectrical parameter/ } \\
\text { Correlation dependence }\end{array}$} & \multicolumn{3}{|c|}{$\begin{array}{c}\text { Parameter variation range (mean value)/ } \\
\text { Correlation equation (correlation coefficient) }\end{array}$} \\
\hline & & Sandstones & Limestones & Dolomites \\
\hline 1 & 2 & 3 & 4 & 5 \\
\hline 1 & $\begin{array}{l}\text { Electrical resistivity } \\
\text { of dry extracted samples }\end{array}$ & $\begin{array}{c}5.2 \cdot 10^{4} \div 1.1 \cdot 10^{7} \\
\left(3.6 \cdot 10^{6}\right)\end{array}$ & $\begin{array}{c}1.3 \cdot 10^{5} \div 6.6 \cdot 10^{6} \\
\left(1.4 \cdot 10^{6}\right)\end{array}$ & $\begin{array}{c}1.5 \cdot 10^{5} \div 2.4 \cdot 10^{7} \\
\left(6.4 \cdot 10^{6}\right)\end{array}$ \\
\hline 2 & $\begin{array}{c}\text { Electrical resistivity of rock } \\
\text { samples saturated with synthetic } \\
\text { brine }(\mathrm{NaCl} \text { solution) }\end{array}$ & $\begin{array}{l}7.2 \div 30 \\
(17.6)\end{array}$ & $\begin{array}{l}50.5 \div 72.9 \\
\quad(63.2)\end{array}$ & $\begin{array}{l}28.7 \div 69.8 \\
\quad(51)\end{array}$ \\
\hline 3 & $\begin{array}{l}\text { Formation resistivity factor }(\mathrm{F}) \\
\text { in laboratory conditions }\end{array}$ & $\begin{array}{l}20.4 \div 85.8 \\
(50)\end{array}$ & $\begin{array}{l}143.9 \div 207.6 \\
(180)\end{array}$ & $\begin{array}{c}81.7 \div 198.7 \\
(145)\end{array}$ \\
\hline 4 & $\begin{array}{l}\text { Formation resistivity factor }(\mathrm{F}) \\
\text { under in situ conditions }\end{array}$ & $\begin{array}{c}36 \div 146 \\
(75)\end{array}$ & - & - \\
\hline 5 & $\begin{array}{c}\text { Archie-Dahnov dependence } \\
\text { (laboratory conditions) }\end{array}$ & $\begin{array}{c}\mathrm{F}=1.675 \cdot \mathrm{PF}^{-1.224} \\
\quad \text { with } \mathrm{R}^{2}=0.84\end{array}$ & $\mathrm{~F}=41 \cdot \mathrm{PF}^{-0.273}$ with $\mathrm{R}^{2}=0.77$ & $\mathrm{~F}=37.6 \cdot \mathrm{PF}^{-0.33}$ with $\mathrm{R}^{2}=0.74$ \\
\hline 6 & $\begin{array}{l}\text { Archie-Dahnov dependence } \\
\quad \text { (in situ conditions) }\end{array}$ & $\begin{array}{c}\mathrm{F}=1.365 \cdot \mathrm{PF}^{-1.519} \text { with } \\
\mathrm{R}^{2}=0.92\end{array}$ & - & - \\
\hline 7 & $\begin{array}{c}\text { Resistivity anisotropy coefficient } \\
\lambda \text { of dry extracted samples }\end{array}$ & $\begin{array}{c}1.01 \div 1.09 \\
(1.05)\end{array}$ & - & - \\
\hline 8 & $\begin{array}{l}\text { Resistivity anisotropy coefficient } \\
\lambda \text { of rock samples saturated with } \\
\text { synthetic brine ( } \mathrm{NaCl} \text { solution) }\end{array}$ & $\begin{array}{l}1.05 \div 1.18 \\
(1.12)\end{array}$ & - & - \\
\hline 9 & Resistivity index (I) & $\begin{array}{c}1 \div 3.24 \\
(1.24)\end{array}$ & $\begin{array}{c}1 \div 7.19 \\
(2.24)\end{array}$ & $\begin{array}{c}1 \div 2.76 \\
(1.44)\end{array}$ \\
\hline 10 & $\begin{array}{l}\text { Correlation between water } \\
\text { saturation factor }\left(\mathrm{S}_{\mathrm{w}}\right) \\
\text { and resistivity index }(\mathrm{I}) \\
\end{array}$ & $\begin{array}{c}\mathrm{I}=1.067 \cdot \mathrm{S}_{\mathrm{w}}^{-0.925} \\
\text { with } \mathrm{R}^{2}=0.82\end{array}$ & $\begin{array}{l}\mathrm{I}=1.09 \cdot \mathrm{S}_{\mathrm{w}}^{-0.86} \\
\text { with } \mathrm{R}^{2}=0.82\end{array}$ & $\mathrm{I}=1.003 \cdot \mathrm{S}_{\mathrm{w}}^{-0.864}$ with $\mathrm{R}^{2}=0.79$ \\
\hline 11 & $\begin{array}{l}\text { Correlation between resistivity } \\
\text { increase }(Q) \text { and pressure }(p)\end{array}$ & $\begin{array}{c}Q=1 \cdot 10^{-5} p^{3}-13 \cdot 10^{-4} \\
p^{2}+5.9 \cdot 10^{-2} \cdot p+0.9993 \\
\text { with } R^{2}=0.99\end{array}$ & $\begin{array}{l}Q=-8 \cdot 10^{-6} \cdot p^{4}+ \\
9 \cdot 10^{-4} \cdot p^{3}-3.06 \cdot 10^{-2} \\
p^{2}+4.045 \cdot p+0.3645 \\
\quad \text { with } R^{2}=0.97\end{array}$ & - \\
\hline 12 & $\begin{array}{c}\text { Coefficient of resistivity increas- } \\
\text { ing with pressure changing from } \\
\text { atmospheric to } 59 \mathrm{MPa}\end{array}$ & $1 \div 2.12$ & $1 \div 7.7$ & - \\
\hline
\end{tabular}

\section{References}

1. Вижва С. А. Петроепектричні доспідження керна свердловини Чорноморського шельфу / С. А. Вижва, М. В. Рева, А. П. Гожик, В. І. Онищук, І. І. Онищук // Вісн. Київ. нац. ун-ту Ім. Т. Г. Шевченка. Сер. Геологія. - 2008. - № 44. - С. 4-8.

S. Vyzhva, N. Reva, A. Gozhyk, V. Onyshchuk I. Onyshchuk, (2008). Petroelectrical investigations of borehole core of Black Sea shelf [Petroelektrychni doslidzhennya kernu sverdlovyny Chornomorskogo shelfu]. Visnyk Kyyivskogo universytetu. Geologiya - Herald of Kyiv University. Geology, 44, 4-8.

2. Вижва С. А. Петроелектричні доспідження керна складнопобудованих порід-колекторів / С. А. Вижва, М. В. Рева, А. П. Гожик, В. І. Онищук, І. І. Онищук // Вісн. Київ. нац. ун-ту Ім. Т. Г. Шевченка. Сер. Геологія. - 2010. - № 50. - С. 4-7.

S. Vyzhva, N. Reva, A Gozhyk, V Onyshchuk I. Onyshchuk, (2010). Petroelectrical investigations of borehole core of complexly-build reservoir rocks [Petroelektrychni doslidzhennya kernu skladnopobudovanyh poredkolektoriv]. Visnyk Kyyivskogo universytetu. Geologiya - Herald of Kyiv University. Geology, 50, 4-7.

3. Вижва С. А. Петроелектрична модель порід-колекторів ЗахідноШебелинського газоконденсатного родовища / С. А. Вижва, Д. І. Онищук, В. І. Онищук // Вісн. Київ. нац. ун-ту Ім. Т. Г. Шевченка. Сер. Геологія. -2012 . - № 57. - С. 13-16.

S. Vyzhva, D. Onyshchuk V. Onyshchuk. (2012). Petroelectrical investigations of reservoir rocks of Western-Shebelynske gas condensate field [Petroelektrychna model porid-kolektoriv Zahidno-Shebelinskogo gazokondensatnogo rodovyshcha]. Visnyk Kyyivskogo universytetu. Geologiya - Herald of Kyiv University. Geology, 57, 13-16.

4. Дахнов В. Н. Геофизические методы определения коллекторских свойств и нефтегазонасыщения пород / В. Н. Дахнов // Недра. - 1975. $343 \mathrm{c}$.

V. Dahnov, (1975). Geophysical methods of assesnent of reservoir characteristics and hydrocarbon saturation of rocks [Geofizicheskie metody opredeleniya kollekorskih svoysvtv i neftegazonasyshcheniya porod] Nedra - Subsurface, 343.

5. Петрофизика : справочник / Н. Б. Дортман. - М. : Недра, 1992. - Ч. 1. $-391 \mathrm{c}$.

N. Dortman, (1992) Petrophysics. Handbook. part 1 [Petrofizika. Spravochnik ch.1]. Nedra - Subsurface, 391.

6. Петрофизика : справочник / Н. Б. Дортман. - М. : Недра, 1992. - Ч. 2. $-304 \mathrm{c}$.

N. Dortman, (1992) Petrophysics. Handbook. part 2 [Petrofizika. Spravochnik ch.2]. Nedra - Subsurface, 304

7. Физические свойства горных пород и полезных ископаемых : справочник геофизика / Н. Б. Дортман. - М. : Недра, 1984. - 455 с.

N. Dortman, (1984). Physical properties of rocks and mineral deposits. Geophysics Handbook [Fizicheskie svoystva gornikh porod I poleznykh iskopaemykh. Spravochnik geofizika]. Nedra - Subsurface, 455

8. Пархоменко Э. И. Электрические свойства горных пород / Э. И. Пархоменко. - М. : Наука, 1965. - С. 164

E. Parkhomenko, (1965). Electrical properties of rocks [Elektricheskie svoystva gornykh porod]. Nauka - Science, 164. 
С. Вижва, д-р. геол. наук, проф.

vsa@univ.kiev.ua,

д. Онищук, інж. I кат. д/б теми 11Бп049-01

boenerges@ukr.net

В. Онищук, канд. геол. наук, асист.

vitus16@ukr.net

Т. Пастушенко, канд. філол. наук

Київський національний університет імені Тараса Шевченка, НнІ "Інститут геології"

вул. Васильківська, 90, м. Київ, 03022, Україна

\section{ЕЛЕКТРИЧНІ ВЛАСТИВОСТІ ПОРІД КЕМБРІЮ ВОЛИНО-ПОДІЛЛЯ}

У статті розелядаються результати та особливості методики петроелектричних досліджень при вивченні складно побудованих карбонатних і теригенних колекторів. Наведено результати визначення електричних параметрів та їхній зв'язок з ємнісними властивостями пісковиків, вапняків і доломітів кембрію Володимирської площі Волино-Поділля. Метою проведених досліджень була розробка та створення петроелектричних моделей порід-колекторів як основи комплексного аналізу їхніх електричних параметрів $i$ зв'язків з ємнісно-фільтраційними властивостями. Комплекс петрофізичних лабораторних досліджень включав визначення: густини досліджених порід (сухих і насичених моделлю пластової води); відкритої пористості (методами насичення азотом і моделлю пластової води); коефіцієнта залишкового водонасичення (методом центрифугування); проникності (методом стаціонарної фільтрації азоту); інтервального часу (швидкості поздовжніх пружних хвиль) і питомого електричного опору. У процесі лабораторних робіт визначався питомий електричний опір зразків порід при різних умовах (сухі, неповністю та повністю насичені розчином-імітатором пластового флюїду) в атмосферних умовах, а також в умовах наближених до пластових.

У результаті виконаних лабораторних досліджень вивчено петроелектричні параметри пісковиків, вапняків і доломітів кембрію Володимирської площі, перспективної на вуглеводні. Установлено, що значення питомого електричного опору сухих екстрагованих зразків (питомий електричний опір мінерального скелета) змінюється від 5,2.104 (пісковики) до 2,4.107 Ом.м (доломіти) при середньому значенні 3,8.106 Ом.м. Питомий електричний опір зразків порід насичених моделлю пластової рідини (розчин NaCl) змінюється від 7,2 (пісковики) до 73 Ом.м (вапняки) при середньому значенні 45 Ом.м. Діапазон зміни відносного електричного опору становить: від 20,4 до 85,5 при середньому значенні 44,1 (пісковики); від 143,9 до 207,6 при середньому значенні 188,6 (вапняки); від 81,7 до 198,7 при середньому значенні 155,6 (доломіти). Діапазон зміни параметра збільшення електричного опору становить: від 1 до 3,24 при середньому значенні 1,24 (пісковики); від 1 до 7,19 при середньому значенні 2,24 (вапняки); від 1 до 2,76 при середньому значенні 1,44 (доломіти). Пісковики мають діапазон зміни коефіцієнта збільшення опору від 1 до 2,12 при збільшенні всебічного тиску від атмосферного до 59 МПа. Для вапняків діапазон зміни коефіцієнта збільшення опору становить від 1 до 7,7 при збільшенні всебічного тиску від атмосферного до 49 МПа.

Установлені емпіричні кореляційні залежності між петроелектричними параметрами та ємнісно-фільтраційними властивостями досліджених порід (між відносним опором і коефіцієнтом пористості в лабораторних і пластових умовах; між параметром збільшення електричного опору та коефіцієнтом водонасичення), що служать основою геологічної інтерпретації геофізичних даних. Ці залежності апроксимуються в більшості випадків степеневою функцією. Аналіз наведених даних свідчить про те, що електрометричні методи є потужним засобом як лабораторних, так і польових досліджень, досить ефективні й надають широку та цінну інформацію про властивості порід.

Ключові слова: дослідження керна, фільтраційно-ємнісні параметри, електричні параметри, поровий простір, кореляційні залежності, пісковик, вапняк, пористість, електричний опір, тиск, проникність, петроелектричні параметри.

С. Выжва, д-р геол. наук, проф.

vsa@univ.kiev.ua,

Д. Онищук, канд. геол. наук, инж. г/б темы 11Бп049-01

boenerges@ukr.net,

В. Онищук, канд. геол. наук, ассист.

vitus16@ukr.net,

Т. Пастушенко, канд. филол. наук

Киевский национальный университет имени Тараса Шевченко,

УНИ "Институт геологии", ул. Васильковская, 90, г. Киев, 03022, Украина

\section{ЭЛЕКТРИЧЕСКИЕ СВОЙСТВА ПОРОД КЕМБРИЯ ВОЛЫНО-ПОДОЛЬЯ}

Рассматриваются особенности методики и результаты петроэлектрических исследований при изучении сложно построенных карбонатных и терригенных коллекторов. Приведены результаты определения электрических параметров и их связь с емкостными свойствами песчаников, известняков и доломитов кембрия Владимирской площади Волыно-Подолья. Целью проведенных исследований была разработка и создание петроэлектрических моделей пород-коллекторов как основы комплексного анализа их электрических параметров и связей с емкостно-фильтрационными свойствами. Комплекс петрофизических лабораторных исследований включал определение: плотности исследованных пород (сухих и насыщенных моделью пластовой воды); открытой пористости (методами насыщения азотом и моделью пластовой воды); коэфффициента остаточного водонасыщения (методом центрифугирования); проницаемости (методом стационарной фильтрации азота); интервального времени (скорости продольных упругих волн) и удельного электрического сопротивления. В процессе лабораторных работ определялось удельное электрическое сопротивление образцов пород при разных условиях (сухие, частично и полностью насыщенные раствором-имитатором пластового флюида) в атмосферных условиях, а также в условиях приближенных к пластовым.

В результате выполненных лабораторных исследований изучены петроэлектрические параметры песчаников, известняков и доломитов кембрия Владимирской площади перспективной на углеводороды. Удельное электрическое сопротивление сухих экстрагированных образцов (удельное электрическое сопротивление минерального скелета) изменяется от 5,2.104 (песчаники) до 2,4.107 Ом.м (доломиты) при среднем значении 3,8.106 Ом.м. Удельное электрическое сопротивление пород, насыщенных моделью пластовой жидкости (раствор NaCl), изменяется от 7,2 (песчаники) до 73 Ом.м (известняки) при среднем значении 45 Ом.м. Диапазон изменения относительного электрического сопротивления: 20,4 - 85,5 при среднем значении 44,1 (песчаники); 143,9 - 207,6 при среднем значении 188,6 (известняки); от 81,7 до 198,7 при среднем значении 155,6 (доломиты). Диапазон изменения параметра увеличения электрического сопротивления: 1 - 3,24 при среднем значении 1,24 (песчаники); 1 - 7,19 при среднем значении 2,24 (известняки); 1 - 2,76 при среднем значении 1,44 (доломиты). Песчаники характеризуются диапазоном изменения коэффициента увеличения сопротивления 1 - 2,12 при увеличения всестороннего давления от атмосферного до 59 МПа. Для известняков диапазон изменения коэффициента увеличения сопротивления составляет 1- 7,7 при увеличения всестороннего давления от атмосферного до 49 МПа.

Установлены эмпирические корреляционные зависимости между петроэлектрическими параметрами и емкостнофильтрационными свойствами исследованных пород (между относительным электрическим сопротивлением и коэффициентом пористости в лабораторных і пластовых условиях; между параметром увеличения сопротивления и коэффициентом водонасыщения), которые служат основой геологической интерпретации геофизических данных. Эти зависимости аппроксимируются в большинстве случаев степенной функцией. Анализ приведенных данных свидетельствует о том, что электрометрические методы являются мощным средством как лабораторных, так и полевых исследований, достаточно эффективны и предоставляют широкую и ценную информацию о свойствах пород.

Ключевые слова: исследование керна, фильтрационно-емкостные параметры, электрические параметры, поровое пространство, корреляционные зависимости, песчаник, известняк, пористость, удельное электрическое сопротивление, давление, проницаемость, петроэлектрические параметры. 